\title{
ПОЗНАВАЊЕ И ОДНЕСУВАҢЕ ВО ОДНОС НА ХЦВ ИНФЕКЦИИ ПОМЕЃУ СТУДЕНТИ НА МЕДИЦИНСКИ ФАКУЛТЕТ, УНИВЕРЗИТЕТ СВ. КИРИЛ И МЕТОДИЈ, СКОПЈЕ
}

\author{
Виктор Исјановски근, Игор Исјановски ${ }^{1}$, Павле Николовски²

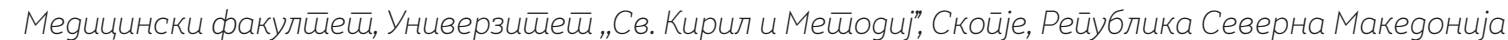

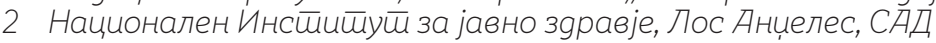

Цитирање: Исјановски В, Исјановски И, Николовски П. Познавање и однесување во однос на ХЦВ инфекции помеѓ студенти на медицински факултет, Универзитет Св. Кирил и Методиј, Скопје. Арх Ј Здравје 2019;11(1):43-50

Клучни зборови: Хепатитис Ц, знаење, ставови, студенти на медицина

*Кореспонденција: Виктор Исјановски, Медицински факултет, Универзитет „Св. Кирил и Методиі", Скопје, Република Северна Македонија. E-mail: viktorisjanovski@yahoo.com

Примено:27-дек-2018; Ревидирано: 20-јан-2019; Прифатено: 28-фев-2019; 0бјавено: 15-мар-2019 Печатарски права: 2019 Виктор Исјановски. Оваа статија е со отворен пристап дистрибуирана под условите на нелокализирана лиценца, која овозможува неограничена употреба, дистрибущија и репродукција на било кој медиум, доколку се цитираат оригиналниот(ите) автор(и) и изворот. Конкурентски интереси: Авторот изјавува дека нема конкурентски интереси.

\section{Извадок}

Цел на студијата е да се утврдат знаењата и ставовите на студентите по медицина за ХЦВ инфекција. Материјал и методи: истражувањето е аналитичка студија на пресек спроведена на Медицинскиот факултет, на примерок од 360 студенти. Анкетирани се студенти од вториот семестар се до завршната година. Притоа користен е специјално дизајниран прашалник, кој е развиен од страна на истражувачот. Пршалникот е составен од три дела: прашање поврзани со социо-демографски податоци, знаење за ХЦВ инфекции и став на студентите кон ХЦВ-позитивни пациенти. Резултати: Стапката на одговор на анкетата беше 90\%. Оваа студија, посочи дека целокупното знаење на студентите по медицина е умерено (многу добро-7-8). Студентите имаат повеќе информации за превенција на хепатит Ц отколку за другите аспекти на болеста, како начин на пренесување и симптоми. Регистрирана е статистички значајна разлика помеѓ знаењето за хепатитис Ц со нивото на образование на студентите. Заклучок: Нашата студија покажа дека студентите по медицина имаат доволно знаење за ХЦВ, но потребно е да се продолж со едукација на оваа тема.

PUBLIC HEALTH

\section{KNOWLEDGE AND ATTITUDES FOR HCV INFECTION AMONG STUDENTS OF THE MEDICAL FACULTY, UNIVERSITY ST.CIRIL \& METODIUS, SKOPJE}

Viktor Isjanovski1 ${ }^{1}$ Igor Isjanovski1, Pavle Nikolovski

Faculty of Medicine, Ss. Cyril and Methodius University in Skopje, Republic of North Macedonia

National Institute of public health, Los Angeles, USA

Citation: Isjanovski V, Isjanovski I, Nikolovski P. Knowledge and attitudes for HCV infection amon students of the medical faculty, University St. Cir \& Metodij, Skopje. Arch Pub Health 2019; 11 (1): 4350 (English)

Key words: Hepatitis C, knowledge, attitude, medical students

*Correspondence: Viktor Isjanovski, Faculty of Medicine Ss. Cyril and Methodius University in Skopje, Republic of North Macedonia. E-mail: viktorisjanovski@yahoo.com

Received: 27-Dec-2018; Revised: 20-Jan-2019; Accepted: 28-Feb-2019; Published: 15-Mar-2019 Copvright:@ 2019. Viktor Isjanovski. This is an open-access article distributed under the terms of open-access article distributed under the terms of the Creative Commons Attribution License, which permits unrestricted use, distribution, and reproduction in any medium, provided the original author(s) and source are credited.

Competing Interests: The author have declared that no competing interests

\section{Abstract}

The aim of the study was to determine knowledge and attitudes for HCV infection among medical students. Material and methods: The research was an analytical cross-sectional study. The study was conducted at Medical faculty, and convenience sample of 360 students, interviewed students of the second semester to final year. Specially designed questionnairy was developed by the researcher It was consisted of three parts include questions related to socio-demographic status, to level of knowledge for HCV infection, and question related to attitude of students towards HCV-positive patients. Results: The response rate of the survey was $90 \%$. The present study, indicated that medical student overall knowledge is moderate (very good 7-8). Students had more information about hepatitis prevention than about other aspects of the disease such as mode of transmission and symptoms, there was a significant correlation among student's attitude and the total level of knowledge toward patients with hepatitis $\mathrm{C}$ in a way that higher knowledge is associated with better attitude. Conclusion: Our study has shown that medical students have a sufficient knowledge about $\mathrm{HCV}$ to face future challenges; they need further education on the subject. 


\section{Introduction}

Hepatitis can be manifested in acute form with jaundice, dark urine, anorexia, weakness, severe fatigue, pain and tender right upper quadrant. Viral hepatitis is one of the five important infectious causes of premature death in the world. At least one million people die from hepatitis in the world yearly. About two billion patients are suffering from hepatitis B, and there are more than 350 million carriers in the world. Hepatitis $\mathrm{C}$ is the most common viral liver disease and about 5.4 million people in the United States are infected with Hepatitis C, based on the results of several studies ${ }^{1}$. The carriers of this disease are about 3\% and 3-4 people become infected annually ${ }^{2-4}$. Around 70 to $80 \%$ of patients with Hepatitis C enter the chronic phase and more than $50 \%$ of them are symptom-free and are not aware of their disease ${ }^{5,6}$. Hepatitis $\mathrm{C}$ is identified as an important factor in chronic liver diseases and liver cancer. Inability caused by Hepatitis $\mathrm{C}$ is not only limited to liver disease; $15 \%$ of cases have extra-hepatic symptoms, including glomerulonephritis, lymphoma, leukemia, Sjogren's syndrome, and lichen planus $^{7-9}$. Also, Hepatitis $C$ is the leading cause of liver transplantation, because of the high prevalence of the disease in the United States ${ }^{10}$. This disease has no vaccine and no cure, because of the high ability of mutations in the genome, and prevention is the only way to avoid it ${ }^{11}$. This infection is currently considered a health-related problem in different communities ${ }^{12}$. Because of the progressive nature of disease, preventing new cases and treating patients in the early stages, are the main methods for controlling it $^{10,13}$. Appropriate perception of HCV (Hepatitis C virus) infection has a great importance among health care workers, because $80 \%$ of patients are initially assessed and diagnosed by them ${ }^{14}$. According to Souza'D and colleagues (2004), the majority of physicians in East London confessed to their little knowledge of chronic Hepatitis $C$ and were in need of further training ${ }^{15}$. Zickmund and colleagues (2007) also assessed the knowledge and attitude of health care workers about HCV and showed that there are defects in their knowledge, which might be a barrier to receiving proper treatment ${ }^{16}$. The research of Laraqui et al (2009), regarding knowledge and function of health care workers in different cities of
Morocco, showed the risks of Hepatitis C and $B$ infections are not respected enough by health care workers ${ }^{17}$.

In the study conducted in Iran, Rahmati Najarkolaei et al. (2013) demonstrated that educational intervention could improve the knowledge of the female students regarding HIV/AIDS ${ }^{18}$.

Medical students are at high risk for occupational exposure to blood-borne pathogens via sharp injuries such as needle stick injuries so it is necessary for students to know about risk factors, diagnosis, treatment, and side effects of Hepatitis $\mathrm{C}^{19}$. On the other hand, epidemiologic researches on Hepatitis C concerning infectious diseases such as AIDS or Hepatitis are limited and few studies have focused on the knowledge and attitude of students about this infection $^{18}$. In Birmingham teaching hospitals, respondents to a questionnaire exhibited substantial lack of knowledge about HBV, $\mathrm{HCV}$, and HIV transmission risks ${ }^{19}$. A study by Janjua et $\mathrm{a}^{20}$ with healthcare workers in Pakistan has shown that education about infections leads to improved use of universal precautions against blood borne pathogens. As students of medicine or nursing as also exposed to the risk of contracting blood borne infections, education on infection control should also include them ${ }^{21}$. According to several studies of clinical practice, patients infected with HBV and HCV suffer from some level of stigmatization and avoidance of care ca-23. $^{22-}$

Hepatitis is a preventable disease and the students of medical sciences have an effective role in its prevention. The staff of health providing services should be familiar not only with treatment but also with epidemiological aspects of diseases such as transmission, prevention and control. Therefore, it is vital to study the level of information of this group in different fields including hepatitis, one of the most prevalent infectious diseases. General knowledge of health staff about viral hepatitis and its transmission and prevention can stop the spread of this disease in hospitals and in society. Since medical students are in constant contact with hepatitis patients during their studying and afterwards, they are in danger of acquiring viral hepatitis especially types $B$ and $C$.

The aim of this study is to determine the knowledge of students of the Medical fac- 
ulty about HCV infections, risk behavior, modes of transmission and prevention

\section{Material and methods}

The research is an analytical cross-sectional study. The research was conducted at the Students of the Medical Faculty. The sample consists of 360 students, began with students in second semester till finish the study. Criteria for exclusion from the study are that the student does not want to participate in the study.

We used a non-standardized, anonymous, self-administering questionnaire, which was already used in a conducted study in Bitola by Prodanovska Stojcevska V. and colleagues ${ }^{24}$ and is validated. The questionnaire is filled out by the students themselves (self-administering). The questionnaire consists of three parts: 1) socio-demographic data; 2) knowledge about HCV infections; and 3) students' attitude toward HCV-positive patients. The first part included data about the age, sex, years of study, type of study, secondary education, nationality, etc.. The second part includes a set of yes / no / I do not know questions about viral pathogenesis, ways of transmission, risk factors (blood transfusion prior to 1995, surgical or gynecological intervention, dental intervention, tattoos, piercings, intravenous drug users, hemodialysis, and exposure to the workplace), symptoms, diagnosis and prevention of infection. The third section includes questions about attitudes towards people who might or have been infected with HCV.

The collected data were organized, tabulated and statistically analyzed using statistical package STATISTICA ${ }^{10}$. Descriptive measures, including frequency, percentage; mean and standard deviation were presented. The significance of the difference is tested by the Difference test. $P$ value was statistically significant at level $0.05 \%$. The collected data are shown in tables and figures.

\section{Results}

Table 1 shows the socio-demographic data for students. The average age of the students are $21.3 \pm 1.6 \mathrm{y}$, a minimum of $18 \mathrm{y}$, and a maximum of $25 y$. $72.2 \%$ of the female sex, $27.8 \%$ of the male sex, the percentage representing the structure of the students at the Medical faculty. 53.6\% are with a gymnasium, secondary medical schools 42.2\% and $4.2 \%$ have another high school. Students are from all years of study, but with a different percentage of representation. 59.2\% of students are from Skopje and $98.6 \%$ were single (table1).

Table 1. Socio - demographic characteristics of the participants

\begin{tabular}{|c|c|c|c|c|}
\hline & average & minimum & maximum & Стд.Дев. \\
\hline Age & 21.3 & 18.0 & 25.0 & 1.6 \\
\hline Gender & \multicolumn{2}{|c|}{ No } & \multicolumn{2}{|c|}{$\%$} \\
\hline Male & \multicolumn{2}{|c|}{100} & \multicolumn{2}{|c|}{27.8} \\
\hline Female & \multicolumn{2}{|c|}{260} & \multicolumn{2}{|c|}{72.2} \\
\hline \multicolumn{5}{|l|}{ School } \\
\hline medical & \multicolumn{2}{|c|}{152} & \multicolumn{2}{|c|}{42.2} \\
\hline gymnasium & \multicolumn{2}{|c|}{193} & \multicolumn{2}{|c|}{53.6} \\
\hline else & \multicolumn{2}{|c|}{15} & \multicolumn{2}{|c|}{4.4} \\
\hline \multicolumn{5}{|c|}{ year of study } \\
\hline $\mathrm{I}$ & \multicolumn{2}{|c|}{63} & \multicolumn{2}{|c|}{17.5} \\
\hline II & \multicolumn{2}{|c|}{31} & \multicolumn{2}{|c|}{8.6} \\
\hline III & \multicolumn{2}{|c|}{137} & \multicolumn{2}{|c|}{38.1} \\
\hline IV & \multicolumn{2}{|c|}{74} & \multicolumn{2}{|c|}{20.6} \\
\hline $\mathrm{V}$ & \multicolumn{2}{|c|}{29} & \multicolumn{2}{|c|}{8.1} \\
\hline VI & \multicolumn{2}{|c|}{26} & \multicolumn{2}{|c|}{7.2} \\
\hline
\end{tabular}




\begin{tabular}{|l|c|c|}
\hline place of living & 213 & 59.2 \\
\hline Skopje & 147 & 40.8 \\
\hline rest & \multicolumn{2}{|c|}{} \\
\hline marital status & 355 & 98.6 \\
\hline single & 5 & 1.4 \\
\hline yes & & \multicolumn{2}{|c|}{} \\
\hline
\end{tabular}

Table 2. Proportion of participants answered correctly statements regarding general knowledge and routs of transmission

\begin{tabular}{|c|c|c|}
\hline General Knowledge/Questions & correct answer & $\%$ \\
\hline Hepatitis c is caused by virus & 350 & 97.2 \\
\hline \multicolumn{3}{|l|}{ risk behavior } \\
\hline blood transfusion before 1995 & 269 & 74.7 \\
\hline surgical intervention & 306 & 85.0 \\
\hline gynecological intervention & 291 & 80.8 \\
\hline dental intervention & 298 & 82.8 \\
\hline placement of piercing & 325 & 90.3 \\
\hline placement of tattoo & 310 & 86.2 \\
\hline using drugs & 296 & 82.2 \\
\hline sniffing cocaine & 116 & 32.2 \\
\hline hemodialysis & 267 & 74.2 \\
\hline Hemophilia & 185 & 51.4 \\
\hline professional exposure & 255 & 70.8 \\
\hline the use of common personal hygiene maintenance equipment & 303 & 84.2 \\
\hline frequently changing sexual partners & 303 & 84.2 \\
\hline the role of the genotype of the virus & 310 & 86.1 \\
\hline Contact with infected blood and blood derivatives & 308 & 85.6 \\
\hline transferred from a positive mother to a child & 285 & 79.2 \\
\hline $\begin{array}{l}79.2 \% \text { of the students give the correct answer, that the virus can } \\
\text { be transmitted from a positive mother to a child }\end{array}$ & 285 & 79.2 \\
\hline Is there a HCV vaccine & 136 & 37.7 \\
\hline Co-infection with HBV & 218 & 60.6 \\
\hline Co-infection with HIV & 240 & 66.7 \\
\hline if there is specific therapy & 171 & 47.5 \\
\hline $\begin{array}{l}\text { have avoided any therapeutic with a diagnosed or suspected } \\
\text { person with hepatitis C }\end{array}$ & 214 & 59.4 \\
\hline $\begin{array}{l}\text { have avoided any contact with a diagnosed or suspected person } \\
\text { with hepatitis C }\end{array}$ & 85 & 23.6 \\
\hline $\begin{array}{l}\text { do they consider that a healthcare worker may refuse / avoid } \\
\text { treatment of HCV + person }\end{array}$ & 156 & 43.3 \\
\hline \multicolumn{3}{|c|}{ No average minim. maxim. Std.Dev } \\
\hline Average assessment of knowledge about HCV infection & $\begin{array}{ll}6.2 & 1.0\end{array}$ & 2.151013 \\
\hline
\end{tabular}

Alarge percentage of respondents answered that Hepatitis $\mathrm{C}$ causes a virus-97.2\%, and $2.8 \%$ consider it a bacterium, the percentage difference is statistically significant for

$\mathrm{p}<0.05$ ( $\mathrm{p}=0.000000)$ (tab 2). The profile of those who give an incorrect response to the causative agent of hepatitis $\mathrm{C}$ are women (80.0\%), Macedonians (60.0\%) and Albanians 
(40.0\%), gymnasium (80.0\%), 50.0\% are in the first year, $20.0 \%$ are second and 30.0\% are third year. The dependence between the study year and the knowledge caused by Hepatitis C (Pearson Chi-square: 11.6186, $\mathrm{p}=.040405)$ is recorded. $74.7 \%$ of those surveyed correctly responded that a blood transfusion before 1995 is a risky behavior for HCV infection. The knowledge of HCV transmission trough surgical, gynecological and dental intervention (if basic hygiene measures are not maintained) ranges from $85.0 \%$ to $80.8 \%$. The respondents' transmission of HCV by setting piercing or tattoo ranging from $90.3 \%$ to $86.2 \%$. A large percentage of respondents $-82.2 \%$ know that i.v. drug use represents a risk behavior for HCV infection. Only $32.2 \%$ of respondents know that sniffing cocaine represents risky behavior for HCV infection (table 2). 74.2\% of respondents know that hemodialysis as a therapeutic method represents a risk for HCV infection. 51.4\% of respondents know that the disease like hemophilia represents risk behavior for HCV infection. 29.2\% of medical students do not know that occupational exposure is a risk, $70.8 \%$ knows. $84.2 \%$ of respondents know that the use of common accessories for personal hygiene, for shaving, toothbrushes and frequently changing sexual partner is a risk (table 2). Knowledge of risk behaviors (factors) for getting HCV infection among surveyed students ranges from 70.8\% (occupational exposure) to $90.3 \%$ (tattoo). The highest percentage of inaccurate responses to risk behaviors (factors) for HCV infection among students is registered in cocaine-sniffing-67.8\% and 48.6- in cases of hemophilia.

Correct response to the role of the genotype of the virus (time duration of the disease and the success of treatment) - give $86.1 \%$ of the students. Correct answer for the transmission of the virus - give $85.6 \%$ of the surveyed students. $66.7 \%$ of the respondents believe that co-infection with HIV is possible and 60.6\% with HBV. $47.5 \%$ of the students consider that there is a specific HCV infection. 35.0\% of the students offered suggestions for preventive measures such as: careful blood and blood derivatives work, sharp objects, careful work in laboratories, wearing two pairs of protective gloves, masks, glasses, education of the population, and information about the transmission.
$59.4 \%$ of those students would not have avoided therapeutic contact with diagnosed or suspected hepatitis C, and $23.6 \%$ would avoid anybody including sexual contact with a diagnosed or suspected hepatitis C disease. $11.4 \%$ of the respondents did not know if they would avoid treatment with a diagnosed or suspected hepatitis C disease, and $14.5 \%$ do not know if they would avoid anybody including sexual contact with a diagnosed or suspected hepatitis C disease. $29.2 \%$ of those would avoid treatment with diagnosed or suspected hepatitis C disease, and $61.9 \%$ would escape anybody including sexual contact with a diagnosed or suspected hepatitis C.

The average assessment of knowledge about HCV infection in 336 students according to their assessment is $6.2 \pm 2.2$, minimum 1 , and a maximum of 10

\section{Discussion}

The current study was conducted among medical students who are expected to have adequate background knowledge and a cautious attitude toward such contagious diseases as hepatitis C. The students have generally shown a high level of knowledge about HCV infection. We believe that this is the result of regular attendance to theoretical and practical classes.

Regarding the mode of HCV transmission, our study has shown that the level of awareness was not poor. However, some questions were good such as those on injections of drug users, infection through blood transfusion, and organ donation. These results were similar to findings reported by the study in University of Lome students25 In the Medical College of Bitola, students showed a high-level of awareness of HCV transmission 24 and more than half of the medical students in medical colleges of Karachi, Pakistan, revealed excellent knowledge of HBV and HCV transmission ${ }^{26}$.

The students in this study showed good knowledge of the clinical presentation of hepatitis C. Similar results on the diagnosis of hepatitis B and C were reported of Karachi medical students ${ }^{26}$ but our results were better than those of the medical students in Guilan University, Iran, which were poor ${ }^{27}$.

Persons with HCV infection are often asymptomatic and may not even be aware that they are infected though they are capa- 
ble of infecting others. ${ }^{28-29}$ Most of the medical students as in the Mansour-Ghanaei's study were unaware of the asymptomatic nature of $\mathrm{HCV}$ infection. ${ }^{27}$ In the present study, most of the medical students knew that persons infected with hepatitis $C$ can be asymptomatic. This was consistent with the responses reported in the study by Khan et $a^{26}$.

The present study reported that more than half of medical students had fair knowledge of the treatment (59.4\%) of Hepatitis $\mathrm{C}$, which was better than the results of $\mathrm{Ka}^{-}$ rachi ${ }^{26}$ and Guilan University medical students $^{27}$.

Half of the studied group, the overall level of awareness of hepatitis $C$ was fair, as in the study of University of Dammam(69.\%) ${ }^{30}$. These results were better than a study among Najran medical students which found poor or inadequate knowledge of blood-borne infections. ${ }^{31}$ The mean knowledge levels of medical students of Guilan University of hepatitis $C$ were relatively low. ${ }^{27}$ In study by Hu et al. Taiwanese dental students were uncertain of HCV infection, and their knowledge level was significantly lower on HCV than HBV and HIV. ${ }^{32}$ However, our study was comparable to the result of a study conducted in medical colleges in Karachi by Khan et al ${ }^{26}$ and University of Dammam ${ }^{30}$, which showed the overall knowledge of students about hepatitis B and $\mathrm{C}$ between 50\% and 70\% (50\%-90\% our study).

\section{Conclusions}

In the current study, the students had knowledge of an fair level, acceptable public perceived risk, and moderate personal perceived risk and behavioral intention. Generally, greater age and education levels of students were associated with increased knowledge and perceived risk (personal and public) among students. As hepatitis is a very important health problem affecting almost $10 \%$ of the population.

Significant feedback between students' attitudes and levels of knowledge is registered. The views are directly influenced by the new knowledge. Therefore, it is necessary to increase the level and quality of training for HCV in order to prevent discrimination and prejudice towards infection and patients.
Successful implementation of the research and realization of the set goals provides the possibility for systemization and assessment of the knowledge and attitudes of medical students for HCV infection and risk factors, thus identifying the key parameters for creating appropriate programs for education and promotion of prevention.

The findings from this research can be used as a basis and improvement of specific targeted programs for raising the awareness of HCV infection and risk factors for its development, as well as proposals for prevention programs.

\section{References}

1. Wong JB, McQuillan GM, McHutchison JG, Poynard T. Estimating future hepatitis C morbidity, mortality, and costs in the United States. American Journal of Public Health 2000; 90(10):1562-1569.

2. Lodi G, Giuliani M, Majorana A, Sardella A, Bez C, Demarosi F, Carrassi A. Lichen planus and hepatitis $C$ virus: a multicentre study of patients with oral lesions and a systematic review. British Journal of Dermatology 2004; 151(6):1172-1181.

3. Harden MD, Skelton H, Smith CK. Lichen planus associated with hepatitis $C$ virus: no viral transcripts are found in the lichen planus, and effective therapy for hepatitis $C$ virus does not clear lichen planus. Journal of the American Academy of Dermatology 2003; 49(5):847-852.

4. Harman M, Akdeniz S, Dursun M, Akpolat N, Atmaca S. Lichen planus and hepatitis $C$ virus infection: an epidemiologic study. International journal of clinical practice 2004; 58(12):1118-1119.

5. Patrick L. Hepatitis C: epidemiology and review of complementary/alternative medicine treatments. Alternative medicine review: a journal of clinical therapeutic 1999; 4(4):220-238.

6. Chainani-Wu N, Lozada-Nur F, Terrault N. Hepatitis $C$ virus and lichen planus: a review. Oral Surgery, Oral Medicine, Oral Pathology, Oral Radiology, and Endodontology 2004; 98(2):171-183.

7. Karavelioğlu D, Koytak ES, Bozkaya H, Uzunalimoğlu O, BozdayiI AM, Yurday- 
din C. Lichen planus and HCV infection in Turkish patients. Turk J 2004; 15 (3):133-136.

8. Campisi G, Fedele S, Lo Russo L, Di Fede $\mathrm{O}$, Arico P, Craxi A, Mignogna MD. HCV infection and oral lichen planus: a weak association when HCV is endemic. Journal of viral hepatitis 2004; 11(5):465-470.

9. Kurokawa M, Hidaka T, Sasaki H, Nishikata I, Morishita K, Setoyama M. Analysis of hepatitis C virus (HCV) RNA in the lesions of lichen planus in patients with chronic hepatitis $\mathrm{C}$ : detection of anti-genomic-as well as genomic-strand HCV RNAs in lichen planus lesions. Journal of dermatological science 2003; 32(1):65-70.

10. Neff GW, O‘Brien CB, Nery J, Shire NJ, Nishida S, delagarza J, Montalbano M, Safdar K, Ruiz P, Rideman E, Gascon JA. Factors that identify survival after liver retransplantation for allograft failure caused by recurrent hepatitis $C$ infection. Liver transplantation 2004; 10 (12):1497-1503.

11. Poynard T, McHutchison J, Manns M, Trepo C, Lindsay K, Goodman Z, Ling $\mathrm{MH}$, Albrecht J. Impact of pegylated interferon alfa-2b and ribavirin on liver fibrosis in patients with chronic hepatitis C. Gastroenterology 2002; 122 (5):13031313.

12. Maticic M. Hepatitis $C$ virus infection: the dermatological perspective. ACTA Dermatolovenerologica Alpina Panonica et Adriatica 2003; 12 (1):19-27.

13. Fried MW, Shiffman ML, Reddy KR, Smith C, Marinos G, Gonçales Jr FL, Häussinger D, Diago M, Carosi G, Dhumeaux D, Craxi A. Peginterferon alfa-2a plus ribavirin for chronic hepatitis $C$ virus infection. New England Journal of Medicine 2002; 347 (13): 975-982.

14. 1Ouzan D, Cavailler P, Hofliger P, Mamino C, Joly H, Tran A. Modalities of care in anti HCV positive patients identified in General Medicine in the Alpes-Maritimes district. Gastroenterol Clin Biol 2003; 27: 376-380.

15. 1d'Souza RF, Glynn MJ, Alstead E, Osonayo C, Foster GR. Knowledge of chronic hepatitis $\mathrm{C}$ among East London primary care physicians following the Department of Health's educational campaign. QJM An International Jour- nal of Medicine 2004; 97 (6):331-336.

16. Zickmund SL, Brown KE, Bielefeldt K. A systematic review of provider knowledge of hepatitis C: is it enough for a complex disease? Digestive diseases and sciences 2007; 52(10):2550-2556.

17. Laraqui O, Laraqui S, Tripodi D, Ouazzani LC, Caubet A, Verger C, Laraqui CH. Evaluation of knowledge, attitudes and practices in the health care setting in Morocco with regard to hepatitis B and C. Sante publique (Vandoeuvre-les-Nancy, France) 2008; 21(3):271-286.

18. Najarkolaei FR, Niknami S, Aminshokravi F, Tavafian SS, Jafari NA, Golabchi A. Promoting sexual abstinence intention among female university students: A quasi-experimental study. Journal of research in medical sciences 2013; 18(1):37-43.

19. Stein AD, Makarawo TP, Ahmad MF. A survey of doctors and nurses knowledge, attitudes and compliance with infection control guidelines in Birmingham teaching hospitals. J Hosp Infect 2003; 54:68-73.

20. Askarian M, Honarvar B, Tabatabaee HR, Assadian O. Knowledge, practice and attitude towards standard isolation precautions in Iranian medical students. J Hosp Infect 2004; 58:292-296.

21. Janjua NZ, Razaq M, Chandir S, Rozi S, Mahmood B. Poor knowledge-predictor of nonadherence to universal precautions for blood borne pathogens at first level care facilities in Pakistan. BMC Infect Dis 2007; 7:81.

22. Butt G. Stigma in the context of hepatitis C: concept analysis. J Adv Nurs 2008; 62:712-724.

23. Kagan I, Ovadia KL, Kaneti T. Perceived knowledge of blood-borne pathogens and avoidance of contact with infected patients. J Nurs Scholarsh 2009; 41:13-19.

24. Prodanovska-Stojčevska V, et al. HCV Infection Awareness in Nursing Students. Arh Hig Rada Toksikol 2010; 61:197-201

25. Bagny A, Bouglouga O, Djibril MA, Kaaga YL, Dusabe A, Lawson AL, et al. Knowledge and attitudes of students towards viral hepatitis B and C at the 
University of Lome. Indian J Gastroenterol 2015; 34:78-79.

26. Khan N, Ahmed SM, Khalid MM, Siddiqui SH, Merchant AA. Effect of gender and age on the knowledge, attitude and practice regarding hepatitis B and $\mathrm{C}$ and vaccination status of hepatitis $B$ among medical students of Karachi, Pakistan. J Pak Med Assoc. 2010; 60:450-455.

27. Mansour-Ghanaei R, Joukar F, Souti F, Atrkar-Roushan Z. Knowledge and attitude of medical science students toward hepatitis B and C infections. Int J Clin Exp Med 2013; 6:197-205

28. Webster DP, Klenerman P, Dusheiko GM. Hepatitis C. Lancet 2015; 385:1124-1135.

29. World Health Organization. Hepatitis C. 2015. Available from: http://www. who.int/mediacentre/factsheets/ fs164/en/

30. Abdulelah H. Almansour, Darwish MA, Abdel Wahab M .M, Hepatitis C infection awareness among fourth year medical students at University of Dammam. J Family Community Med 2017; 24(1): 49-54.

31. Alqahtani JM, Abu-Eshy SA, Mahfouz AA, El-Mekki AA, Asaad AM. Seroprevalence of hepatitis $B$ and $C$ virus infections among health students and health care workers in the Najran region, Southwestern Saudi Arabia: The need for national guidelines for health students. BMC Public Health 2014; 14:577

32. Hu SW, Lai HR, Liao PH. Comparing dental students' knowledge of and attitudes toward hepatitis B virus-, hepatitis C virus-, and HIV-infected patients in Taiwan. AIDS Patient Care STDS 2004; 18:587-593 